\title{
HISTORIOGRAFI KAUSA LEGAL BUNGA (RIBA) DI INDONESIA
}

\author{
Fanani Mafatikul Ihsan \\ Fakultas Ekonomi dan Bisnis, Universitas Airlangga \\ Email: fanani@,dakonwork.com
}

Ridan Muhtadi

Prodi Ekonomi Syariah, STAI Miftahul Ulum Pamekasan

Email: ridanmuhtadi@gmail.com

Moh Subhan

STAI Miftahul Ulum Pamekasan

Email: orsatpmk@gmail.com

\begin{abstract}
The discourse on interest can be said to be a "classic" problem both in the development of Islamic thought or in the history of human civilization. Because interest can not be separated from the economic activities of humanity. In Indonesia, interest has become transactions in the economic field in general. Until now interest collection still occurs in various commercial activities, both in the sale and purchase activities, accounts payable and other transactions. In Islamic teachings, economic activities carried out by humans have some rules and ethics or morality in Islamic law. However, the stipulation of interest as usury still needs an in-depth study, especially in terms of the history of legality stipulated in a fatwa in Indonesia.
\end{abstract}

Keywords: Historiography, Legal fatwa, Interest (Riba).

\begin{abstract}
Abstrak
Diskursus tentang bunga dapat dikatakan permasalahan "klasik" baik dalam perkembangan pemikiran islam ataupun pada sejarah peradaban manusia. Sebab, bunga tidak bisa dipisahkan dari aktivitas ekonomi umat manusia. Di Indonesia, Bunga telah menjadi transaksi-transaksi pada bidang perekonomian secara umum. Hingga saat ini pengambilan bunga masih saja terjadi diberbagai aktivitas perniagaan, baik dalam aktivitas jual beli, hutang piutang, maupun transaksi-transaksi lainnya. Dalam ajaran islam, aktifitas ekonomi yang dilakukan oleh manusia memiliki beberapa kaidah dan etika atau moralitas dalam syariat islam. Namun penetapan bunga sebagai riba masih perlu pengkajian secara mendalam, terutama dalam hal sejarah ditetapkan secara legalitas dalam fatwa di Indonesia.
\end{abstract}


Kata Kunci: Historiografi, Legal fatwa, Bunga (Riba)

\section{Pendahuluan}

Dalam perekonomian modern, pada dasarnya perbankan menjadi lembaga perantara dan penyalur dana antara pihak yang berkelebihan dengan pihak yang kekurangan dana. Peran ini disebut sebagai financial intermediary. Dengan kata lain, pada dasarnya tugas bank adalah menerima simpanan dan memberi pinjaman. Dan sesuai dengan kebutuhan manusia yang begitu kompleks, jasa yang diberikan bank juga demikian, seperti penukaran mata uang, pengiriman uang dari satu tempat ke tempat lain, mengeluarkan dan mengedarkan uang. Dengan begitu, bank berperan melancarkan transaksi perdagangan dan pembayaran serta memberi perlindungan keamanan uang dari berbagai gangguan, seperti perampokan. ${ }^{1}$

Begitu besar jasa pelayanan lembaga perbankan bagi negara dan masyarakat di masa modern ini sehingga tidak salah jika dikatakan bahwa di dalam suatu negara harus berdiri bank, tanpa ada bank suatu negara akan kacau. Akan tetapi, meskipun memberi jasa pelayanan, tetapi bank bukan lembaga sosial. Bank adalah lembaga yang bergerak dalam usaha dagang. Oleh karena itu, keuntungan menjadi sasaran penting dalam usahanya. Sebagai lembaga yang berkecimpung di dalam peredaran uang, maka barang dagangan bank adalah uang dan jasa. ${ }^{2}$

Membicarakan bank dalam Islam, tidak bisa dilepaskan dari perdebatan tentang bunga, di mana oleh sebagian ulama bunga dianggap sebagai riba yang diharamkan dalam al- Qur'an secara qath'iy. Perdebatan tentang apakah bunga bank termasuk riba atau bukan, telah berlangsung lama dan sampai sekarang masih hangat diperbincangkan, bahkan, menimbulkan pro dan kontra di kalangan umat Islam. Keberagaman interpretasi tentang riba dan relevansinya dengan bunga bank, disebabkan karena perbedaan pendekatan yang dipakai dalam menganalisis ayat-ayat riba.

Dalam karya tulis ini mencoba membahas yang mengaitkan antara riba dan bunga perbankan serta perkembangan kausa legal bunga sebagai riba di Indonesia. Dari perumusan fatwa oleh beberapa organisasi islam berbasis kemasyarakatan seperti Muhammadiyah dan Nahdatul Ulama hingga pada tataran organisasi islam berbasis kepemerintahan yaitu Majelis Ulama Indonesia.

\footnotetext{
${ }^{1}$ Muh. Zuhri, Riba dalam Al-Qur'an dan Masalah Perbankan: Sebuab Tilikan Antisipatif, (Jakarta: PT. RajaGrafindo Persada, 1996) hal 110

${ }^{2}$ Ibid, hal 144
} 
Jenis karya tulis ini secara keseluruhan merupakan jenis karya tulis deskriptif (descriptive research) dengan penelitian kualitatif, yaitu prosedur penelitian yang menghasilkan data deskriptif berupa kata-kata tertulis dari orang-orang dan perilaku yang diamati, didukung dengan studi literatur atau studi kepustakaan berdasarkan pendalaman kajian pustaka berupa data dan angka, sehingga realitas dapat dipahami dengan baik (Moleong, 2013). ${ }^{3}$

Karya tulis ini menggunakan metode pengumpulan data yang dilakukan dengan cara penelitian studi kepustakaan, yaitu dengan cara mempelajari, mendalami dan mengutip teori-teori atau konsep-konsep dari sejumlah literatur seperti jurnal, buku, dan lain-lain.

\section{Konseptualisasi dan Macam-Macam Riba}

Akar kata riba adalah rangkaian huruf ra' dan ba', dan huruf 'illat. Menurut bahasa riba' berarti ziyadah (tambahan) dan nama (tumbuh). Ibn Manzur dalam kitab Lisan al-Arab "riba" berarti tambahan (ziyadah) atau kelebihan (fad). Lafal , ربا, ربو ا, رباء , mengandung arti yang sama, yaitu زيادة , bertambah dan tumbuh (berkembang). ${ }^{4}$ Kecuali itu, riba juga berarti النمو (berkembang/pertumbuhan), الارتفاع (meningkat/naik), dan العلو (ketinggian). ${ }^{5}$ Di Indonesia, term riba sama populernya dengan term bunga. Kata yang disebutkan pertama sering kali diartikan sebagai keutungan yang didapatkan dengan jalan haram. ${ }^{6}$

$$
\begin{aligned}
& \text { أ....... تكون أمة هي أربى من أمة.... }
\end{aligned}
$$

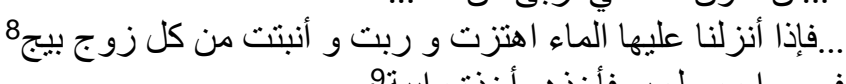

Term "riba" dan derifatnya dalam ayat-ayat di atas masih bermakna umum, yakni bertambah, seperti bertambah subur (rabat), lebih banyak (arba), dan sangat (rabiyah). Jadi belum menunjukkan kepada arti tambahan (ziyadab) secara khusus dalam akad muamalat, seperti jual-beli dan utang piutang. Kaitannya dengan terminologi "riba" dalam transaksi jual beli atau hutang piutang.

Pengertian riba di dalam kamus adalah kelebihan atau peningkatan atau surplus. Tetapi dalam ilmu ekonomi, riba merujuk pada kelebihan dari jumlah uang pokok yang dipinjamkan oleh si pemberi pinjaman dari si peminjam.

\footnotetext{
${ }^{3}$ Moleong, Lexy. 2013. Metode Penelitian Kualitatif (edisi revisi). Bandung: Rosdakarya, hal 05

${ }^{4}$ Abdul Mughits, Ketidakpastian jenis dan Kriteria Hukum Riba dalam Perspektif Pemikiran Ulama. (Jurnal Asy-Syir'ah Vol. 43 No. 1. 2009) hal 78

${ }^{5}$ Heri Sudarsono, Bank dan Lembaga Keuangan Syariab Deskripsi dan Ilustrasi, (Yogyakarta: Ekonisia UII, 2007) hal 10; lihat juga Abdul Aziz Muhammad Azzam, Fiqh Muamalah Sistem Transaksi dalam Figh Islam, (Jakarta: Amzah, 2010) hal 215; Tarek el- Diwany, Bunga Bank dan Masalahnya, (Jakarta Timur: Akbar, 2008) hal 170.

${ }^{6}$ Pius A Partanto dan M. Dahlan al-Barry, Kamus Imiah Populer, (Surabaya: Arkola,tt) hal 678.

${ }^{7}$ Q.S. An-Nahl [16]: 92.

${ }^{8}$ Q.S. Al-Hajj [22]: 5.

${ }^{9}$ Q.S. Al-Haqqah [69]: 10.
} 
Dalam Islam, riba secara khusus menunjuk pada kelebihan yang diminta dengan cara yang khusus. ${ }^{10}$

Pertambahan juga bisa disebabkan oleh faktor interen dan juga bisa faktor eksteren. Dalam Al-Qur'an terdapat beberapa kata yang seakar dengan kata riba. Meskipun masing-masing kata mempunyai pengertian teknis yang berbeda, tetapi terdapat unsur kesamaan, yaitu "tambah/lebih". Sebab dalam praktiknya pihak yang meminjamkan sesuatu meminta tambahan dari sesuatu yang dipinjamkannya. ${ }^{11}$ Akan tetapi, tidak semua bentuk tambahan atas modal pokok yang ditransaksikan itu dilarang dalam Islam. Profit yang didapatkan dalam suatu usaha juga berpotensi menambah nilai pokok modal yang diinvestasikan, namun profit tersebut tidak dilarang dalam Islam. ${ }^{12}$

Mayoritas madzhab fiqh membagi riba menjadi dua, yaitu riba nasi'ah dan riba fadl. Sedangkan madzhab asy-Syafi"i membaginya menjadi tiga, yaitu riba nasi'ah, riba fadl, dan riba yad. Di kalangan jumhur ulama fiqh, riba yad dimasukkan kategori riba nasi'ah. Perbedaan riba nasiah dengan riba yad di dalam madzhab asy-Syafi"i adalah pada riba nasi'ah ketika terjadi akad benda yang diakadkan sudah ada dan dapat diserahterimakan, sedangkan pada riba yad benda yang diakadkan belum ada ketika terjadi akad. ${ }^{13}$

\section{A. Dasar Hukum Larangan Riba}

Larangan riba yang terdapat dalam al-Qur'an tidak diturunkan sekaligus melainkan secara bertahap, penjelasan ini terdapat dalam bukunya Sayyid Quthb tafsir ayat ar-Riba dan Abul A'la al-Maududi14. Empat tahap tersebut sebagai berikut: Tahap pertama, menolak anggapan bahwa pinjaman riba yang pada zahirnya seolah-olah menolong mereka yang memerlukan sebagai suatu perbuatan mendekati atau taqarrub kepada Allah Swt. QS. Ar-Rum: 39:

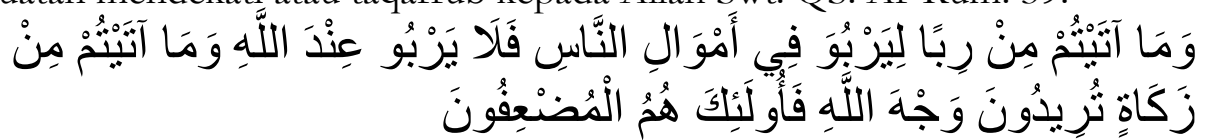

Artinya: "Dan sesuatu riba (tambahan) yang kamu berikan agar dia bertambah pada harta manusia, Maka riba itu tidak menambah pada sisi Allah. Dan apa yang kamu berikan berupa zakat yang kamu maksudkan untuk mencapai keridhaan Allah, Maka (yang berbuat demikian) Itulah orang-orang yang melipat gandakan (pahalanya)". (QS. ar-Rum: 39)

\footnotetext{
${ }^{10}$ Muhammad Nafik H.R., Benarkah Bunga Haram? (Surabaya, Amanah Pustaka: 2009), hal 94.

${ }^{11}$ Ismail Nawawi, Fikih Muamalab Klasik dan Kontemporer, (Bogor: Ghalia Indonesia, 2012) hal 69.

${ }^{12}$ Dimyauddin Djuwaini, Pengantar Figh Muamalah, (Yogyakarta: Pustaka Pelajar, 2008) hal 192.

${ }^{13}$ Wahbah az-Zuhaili, Al-Fiqh al-Islami wa Adillatubu, (Beirut: Dar al-Fikr, 1985), IV: hal 674.

${ }^{14}$ Muhammad Syafi'I Antonio, Bank Syari'ah dari Teori ke Praktek, Jakarta : Gema Insani, 2001, hal. 84
} 
Tahap kedua, riba digambarkan suatu yang buruk. Allah Swt. mengancam akan memberi balasan yang keras kepada orang Yahudi yang memakan riba seperti yang terdapat dalam al-Qur'an Surat anNisa' ayat 160-161

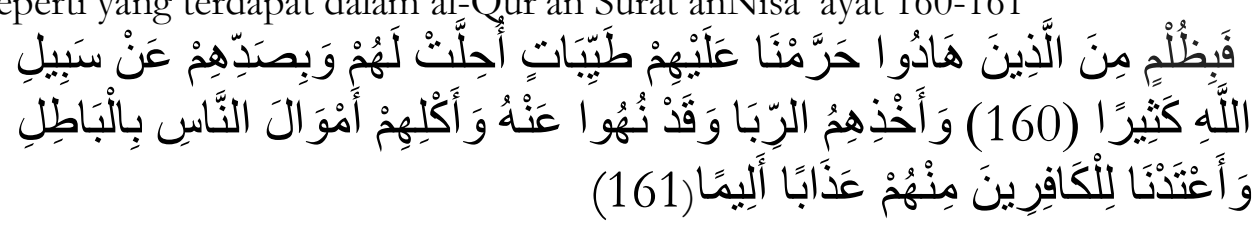

Artinya: Disebabkan kezaliman orangorang Yahudi, Kami haramkan atas mereka (memakan makanan) yang baik-baik (yang dahulnya) dihalalkan bagi mereka, dan karena mereka banyak menghalangi (manusia) dari jalan Allah, dan disebabkan mereka memakan riba, padahal sesungguhnya mereka telah dilarang dari padanya, dan karena mereka memakan harta orang dengan jalan yang batil. Kami telah menyediakan untuk orang-orang yang kafir di antara mereka itu siksa yang pedih. (QS. an-Nisa': 160 - 161)

Tahap ketiga, riba diharamkan dengan dikaitkan kepada suatu tambahan yang berlipat ganda. Para ahli tafsir berpendapat bahwa pengambilan bunga dengan tingkat yang cukup tinggi merupakan fenomena yang banyak dipraktekkan pada masa tersebut. Allah berfirman dalam QS. Ali-Imron: 130:

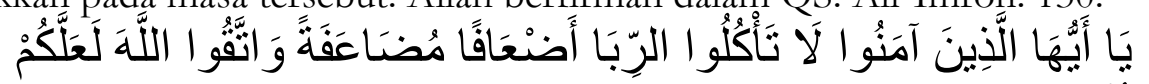

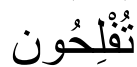

Artinya: "Hai orang-orang yang beriman, janganlah kamu memakan riba dengan berlipat ganda dan bertakwalah kamu kepada Allah supaya kamu mendapat keberuntungan". (QS. Ali-Imron: 130)

Ayat ini turun pada tahun ke-3 Hijriyah. Secara umum, ayat ini harus dipahami bahwa kriteria berlipat ganda bukanlah merupakan syarat dari terjadinya riba, tetapi ini merupakan sifat umum dari praktek pembungaan uang pada saat itu.

Tahap keempat, Allah Swt dengan jelas dan tegas mengharamkan apapun jenis tambahan yang diambil dari pinjaman. Ayat ini merupakan ayat terakhir yang berkaitan dengan riba.

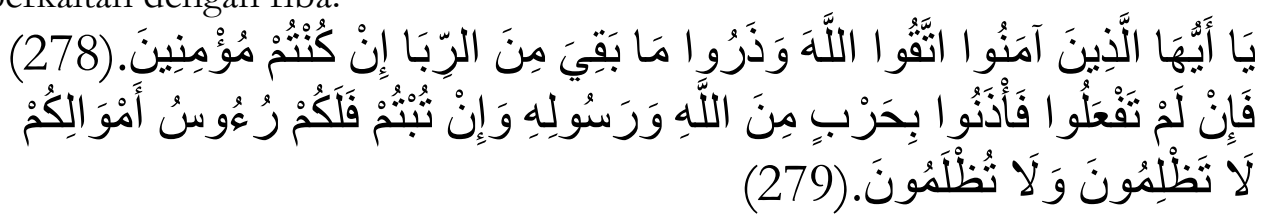

Artinya: "Hai orang-orang yang beriman, bertakwalah kepada Allah dan tinggalkan sisa riba (yang belum dipungut) jika kamu orang-orang yang beriman. Maka jika kamu tidak. mengerjakan (meninggalkan sisa riba), Maka Ketahuilah, babwa Allah dan rasul-Nya akan memerangimu. dan jika kamu bertaubat (dari pengambilan riba), Maka bagimu pokok hartamu; kamu tidak menganiaya dan tidak (pula) dianiaya". (QS. al-Baqarah: $278-279)$ 
Pelarangan riba dalam Islam tidak hanya merujuk pada al-Qur'an saja tetapi juga di dalam al- Hadits. Hal ini sebagaimana fungsi hadits yaitu sebagai penjelas lebih lanjut aturan yang telah digariskan melalui al-Qur'an. Adapun hadits-hadits yang berkenaan dengan dilarangnya riba sebagai berikut.

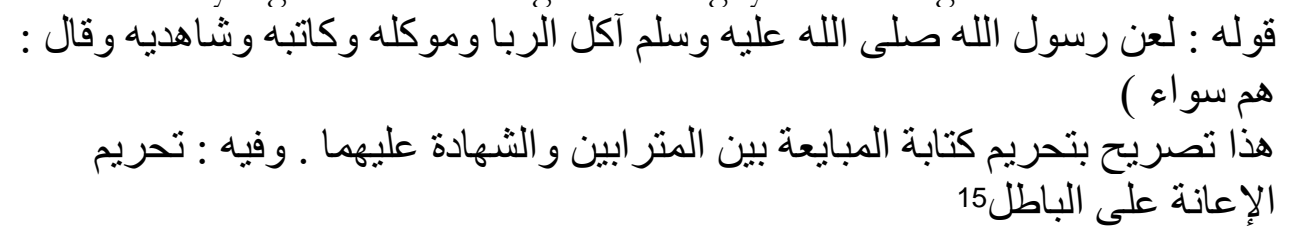

Artinya: "Dari Jabir, Rasulullah melaknat riba, yang mewakilkannya, penulisnya dan yang menyaksikannya”. (HR. Muslim)

Hadits riwayat Abu Dawud, yang artinya: "Dari Sulaiman Ibn 'Amr, dari ayahnya (dilaporkan bahwa) ia berkata: Saya mendengar Rasulullah Saw bersabda pada waktu Haji Wada'. Ketahuilah bahwa setiap bentuk riba Jahiliah telah dihapus; bagimu pokok hartamu, kamu tidak menzalimi dan tidak dizalimi”. (HR. Abu Dawud)

Hadits Abu Hurairah yang artinya: Rasulullah Saw. bersabda: Hindarilah tujuh dosa-dosa besar. Kemudian bertanya apakah yang dimaksud dengan tujuh dosa besar ya Rasulullah? Beliau menjawab: menyekutukan Allah, melakukan sihir, membunuh jiwa yang diharamkan Allah membunuhnya tanpa hak, makan harta anak yatim, makan riba, lari dari medan pertempuran, dan mencemarkan nama baik wanita mukmin yang lengah (HR. Jama'ah ahli Hadis).

Para ulama salaf generasi Sahabat sampai Tabi'i at-Tabi'in bersepakat bahwa hukum riba an-nasi'ah (riba al-qard) itu haram. ${ }^{16}$ Yang masih menjadi diperselisihkan ada tiga hal, yaitu: (1) tentang batasan yang diharamkan dalam riba an-nasi'ab; (2) status hukum riba al-fadl (riba al-bai); dan (3) barang-barang yang termasuk ribawi dalam kasus riba al-fadl, bagi yang menerima status hukum riba al-fadl sebagai riba yang terlarang.

\section{B. Perkembangan Kausa Legal Riba (Bunga Bank) di Indonesia}

Di antara dampak ekonomi riba adalah dampak inflatoir yang diakibatkan oleh bunga sebagai biaya uang. Hal tersebut disebabkan karena salah satu elemen dari penentuan harga adalah suku bunga. Semakin tinggi suku bunga, semakin tinggi juga harga yang akan ditetapkan pada suatu barang. Dampak lainnya adalah bahwa utang, dengan rendahnya tingkat penerimaan peminjam dan tingginya biaya bunga, akan menjadikan peminjam tidak pernah keluar dari ketergantungan, terlebih lagi bila bunga atas utang tersebut dibungakan. Contoh paling nyata adalah utang negara-negara berkembang kepada negara-negara

15 As-Sayyid Sabiq, Figh as-Sunnah, cet. 4 (Beirut: Dar al-Fikr, 1403/1983), III: hal 176
16 As-Sayyid Sabiq, Figh as-Sunnah, cet. 4 (Beirut: Dar al-Fikr, 1403/1983), III: hal 176 
maju. Meskipun disebut pinjaman lunak, artinya dengan suku bunga rendah, pada akhirnya negara-negara pengutang harus berutang lagi untuk membayar bunga dan pokoknya. Akibatnya, terjadilah utang yang terus-menerus. Ini yang menjelaskan proses terjadinya kemiskinan struktural yang menimpa lebih dari separoh masyarakat dunia. ${ }^{17}$

Riba merupakan pendapatan yang didapat secara tidak adil. Para pengambil riba menggunakan uangnya untuk memerintahkan orang lain agar berusaha dan mengembalikan, misalnya, dua puluh lima persen lebih tinggi dari jumlah yang dipinjamkannya. Persoalannya, siapa yang bisa menjamin bahwa usaha yang dijalankan oleh orang itu nantinya mendapatkan keuntungan lebih dari dua puluh lima persen? Semua orang, apalagi yang beragama, tahu bahwa siapa pun tidak bisa memastikan apa yang terjadi besok atau lusa. Siapa pun tahu bahwa berusaha memiliki dua kemungkinan: berhasil atau gagal. Dengan menetapkan riba, orang sudah memastikan bahwa usaha yang dikelola pasti untung. ${ }^{18}$

Berbagai fatwa tentang bunga bank telah dikeluarkan oleh ormas-ormas Islam baik nasional maupun internasional. Berikut ini adalah keputusankeputusan penting yang telah dibuat oleh ormas berkaitan dengan bunga bank:

1. Majelis Tarjih Muhammadiyah

Latar belakang diharamkannya bunga bank oleh Muhammadiyah adalah sistem ekonomi berbasis bunga (interest) semakin diyakini sebagai berpotensi tidak stabil, tidak berkeadilan, menjadi sumber penyakit ekonomi modern, menggantungkan pertumbuhan pada penciptaan hutang baru, merupakan pemindahan sistematis uang dari orang yang memiliki lebih sedikit uang kepada orang yang memiliki lebih banyak uang.

Majelis Tarjih Sidoarjo (1968) memutuskan :

- Riba hukumnya haram dengan sharih Al-Qur'an dan As-Sunnah

- Bank dengan sistem riba, hukumnya haram dan bank tanpa riba hukumnya halal

- Bunga yang diberikan oleh bank-bank milik negara kepada nasabah atau sebaliknya yang selama ini berlaku termasuk perkara mutasyabihat (meragukan)

- Menyarankan kepada PP Muhammadiyah untuk mengusahakan terwujudnya konsepsi sistem perekonomian, khususnya lembaga perbankan, yang sesuai dengan kaidah Islam

Majelis Tarjih Wiradesa, Pekalongan (1972) memutuskan :

\footnotetext{
${ }^{17}$ Muhammad Syafi'i Antonio, Bank Syari'ah Dari Teori Ke Praktik, Jakarta: Gema Insani, 2001, hal. 67

${ }^{18}$ Ibid
} 
- Mengamanatkan kepada PP Muhammadiyah untuk segera dapat memenuhi keputusan majelis tarjih Sidoarjo 1968 tentang terwujudnya konsepsi sistem perekonomian, khususnya lembaga perbankan yang sesuai dengan kaidah Islam.

- Mendesak Majelis Tarjih PP Muhammadiyah untuk dapat mengajukan konsepsi tersebut dalam muktamar yang akan datang

Majelis Tarjih (2006) memutuskan:

- Ekonomi Islam adalah sistem ekonomi yang berbasis nilainilai antara lain berupa keadilan, kejujuran, bebas bunga dan memiliki komitmen terhadap peningkatan kesejahteraan

- Untuk tegaknya ekonom Islam, Muhammadiyah sebagai gerakan dakwah Islam amar ma'ruf nahi munkar dan tajdid perlu terlibat secara aktif dalam mengembangkan dan mengadvokasi ekonomi Islam dalam kerangka kesejahteraan bersama.

- Bunga (interest) adalah riba karena Merupakan tambahan atas pokok modal yang dipinjamkan, Tambahan itu bersifat mengikat dan diperjanjikan, sedangkan yang bersifat sukarela yang tidak diperjanjikan tidak termasuk riba.

- Lembaga keuangan syari'ah diminta untuk terus mengingkatkan kesesuaian operasionalisasi dengan prinsip-prinsip syari'ah.

Fatwa larangan untuk bermuamalah dengan lembaga konvensional ini tidak berlaku mutlak. Untuk wilayah yang belum ada kantor atau jaringan lembaga keuangan syari'ah diperbolehkan melakukan kegiatan transaksi berdasarkan prinip darurat atau hajjat (kebutuhan). Adapun untuk wilayah yang sudah banyak terdapat kantor atau jaringan lembaga keuangan syari'ah mutlak tidak diperbolehkan melakukan transaksi yang didasarkan kepada perhitungan bunga. ${ }^{19}$ Selain itu yang melatarbelakangi diharamkannya bunga bank yaitu kaum muslimin seluruhnya telah sepakat (Ijma') bahwa hukum dasar riba adalah haram, terutama sekali riba pinjaman atau hutang. Bahkan mereka telah berkonsensus dalam hal itu pada setiap masa dan tempat. Para Ulama ahli Fiqh seluruh mazhab telah menukil ijma' tersebut. memang ada perbedaan pendapat sebagian bentuk aplikasinya, namun tidak bertentangan dengan asal ijma' yang telah diputuskan dalam persoalan itu. ${ }^{20}$

2. Lajnah Bahsul Masa'il Nahdlatul Ulama

Persoalan bank dan bunganya dalam pandangan Nahdlatul Ulama (NU) telah menjadi persoalan yang signifikan, sehingga perlu mendapat

${ }^{19}$ Fatwa Majlis Tarjih Muhamadiyah No. 8 Th 2006

${ }^{20}$ Nanang Novandra, Keharaman Bunga Bank. Menurut Fatwa Majelis Tarjih Muhammadiyah No. 08 Tabun 2006 (Studi Tentang Metode Penetapan Hukumnya). Jurnal Tajdida, Vol. 8 No. 2, Desember 2010. hal 238-240 
perhatian yang cukup besar dari para ulama NU. Kaitannya dengan masalah bunga bank, NU melalui forum kajian Bahsul Masailnya telah mengaharamkannya, hal ini dikarenakan bunga bank disamakan dengan gadai yang digunakan pada zaman jahiliyah, jika pemilik barang gadai tidak bisa membayar uang pada waktunya, maka barang gadaiannya lepas dari pemiliknya dan menjadi milik penggadai dan hal ini telah ditetapkan hukumnya dalam Mu'tamar NU ke-2 Tahun 1927 di Surabaya.

Menurut Lajnah dari beberapa kali siding, hukum bank dan bunga sama seperti gadai. Ada tiga pendapat ulama, yaitu: ${ }^{21}$

- Haram, sebab termasuk utang yang dipungut rente

- Halal, sebab tidak ada syarat pada waktu akad, sedangkan adat yang berlaku tidak dapat begitu saja dijadikan syarat

- Syubhat (tidak tentu halal haramnya) sebab para ahli hukum berselisih pendapat tentangnya

Meskipun ada perbedaan pandangan, Lajnah memutuskan bahwa (pilihan) yang lebih berhati-hati adalah pendapat pertama, yakni menyebut bunga bank haram. Kesepakatan tentang hukum bunga bank, tampaknya para muktamirin masih berbeda pendapat, terutama dalam Munas 'Alim Ulama di Bandar Lampung, 21-25 Januari 1992, khususnya mengenai hukum bunga bank konvensional. Di antaranya sebagai berikut :22

- Ada pendapat yang mempersamakan antara bunga bank dengan riba secara mutlak, sehingga hukumnya adalah haram.

- Ada pendapat yang tidak mempersamakan bunga bank dengan riba, sehingga hukumnya adalah boleh.

- Ada pendapat yang mengatakan bunga bank hukumya syubhat (tidak identik dengan riba). Meski begitu, Munas memutuskan, pilihan yang lebih berhati-hati adalah bunga bank haram.

NU sependapat bahwa riba hukumnya adalah haram, hal ini berdasarkan pada nas sarib al-Qur'an dan al-Hadis-yang dengan jelasjelas telah mengharamkan adanya praktik riba. Bagi NU bahwa hukum bunga bank adalah haram baik itu bank milik swasta maupun bank milik negara.

Lebih lanjut, NU mengungkapkan bahwa bunga yang diambil oleh penabung di bank adalah riba yang diharamkan. Artinya, apa yang

${ }^{21}$ Moh. Nashiruddin A. Ma'mun, S.H.I., M.Hum.Perspektif Nu Tentang Bunga Bank (Refleksi Hasil Mu'tamar Nu Ke-2 Tabun 1927 Di Surabaya Dan Munas 'Alim Ulama Di Bandar Lampung Tabun 1992).Jurnal Ummul Qura Vol. 5 No. 1, Maret 2015. hal 121

${ }^{22}$ Ibid, hal 122 
diambil seseorang tanpa melalui usaha perdagangan dan tanpa bersusah payah sebagai tambahan pokok hartanya, maka yang demikian itu termasuk riba. NU kemudian menguatkan pendapatnya, bahwa pengambilan bunga bank oleh nasabah yang menyimpan uangnya di bank adalah haram. Dalam hal ini NU lebih tegas dalam menetapkan keharaman bunga bank-yaitu apabila pihak bank menggunakannya untuk perbuatan yang telah dilarang agama.

3. Majelis Ulama Indonesia (MUI)

Ketika membicarakan riba dalam konteks modern, memang bayangan sebagian besar orang pasti akan tertuju pada bunga bank/ interest (fawaid al-bunuk). Di Indonesia, MUI telah beberapa kali mencetuskan wacana tersebut, masing-masing pada tahun 1990 yang diikuti dengan berdirinya bank syariah pertama yaitu Bank Muamalat Indonesia, kemudian pada tahun 2000 Dewan Syariah Nasional mengeluarkan fatwa bahwa penerapan suku bunga bank bertentangan dengan syariah Islam.

Majelis Ulama Indonesia pada tanggal 16 Desember 2003 mengeluarkan fatwa bahwa bunga bank termasuk dalam kategori riba yang dikukuhkan pada 6 Januari 2004. Fatwa tentang bunga bank adalah riba bukanlah wacana baru bagi umat Islam. dalam penetapan tersebut; Pertama, Pengertian Bunga dan Riba adalah sama. Kedua,secara hukum keduanya dilarang. ${ }^{23}$

Dalam hal ini fatwa dan sosialisanya oleh para ulama dapat dikatakan sebagai 'pendekatan religius'. Selain 'pendekatan religius' diperlukan pendekatan lainnya yang bersifat 'material', dalam hal ini merupakan bidang garapan insan perbankan syari'ah, karena faktor penting yang mendasari pertimbangan bagi nasabah dalam memilih layanan perbankan antara adalah kepereayaan atas kinerja profersional perbankan, seperti jaminan keamanan dana nasabah, efektiiitas dan efisien layanan jasa perbankan.

\section{Kesimpulan}

Dari uarain makalah di atas, maka dapat disimpulkan bahwa riba merupakan kegiatan eksploitasi dan tidak memakai konsep etika atau moralitas. Allah mengharamkan transaksi yang mengandung unsur ribawi, hal ini disebabkan mendholimi orang lain dan adanya unsur ketidakadilan (unjustice). Para ulama sepakat dan menyatakan dengan tegas tentang pelarangan riba, dalam hal ini mengacu pada Kitabullah dan Sunnah Rasul serta ijma' para ulama'.

Transaksi riba biasanya sering terjadi dan ditemui dalam transaksi hutang piutang dan jual beli. Hutang piutang merupakan transaksi yang rentan akan

\footnotetext{
${ }^{23}$ Fatwa MUI Nomor 1 Tahun 2004 tentang Bunga
} 
riba, di mana kreditor meminta tambahan kepada debitor atas modala awal yang telah dipinjamkan sebelumnya. Riba disamaartikan dengan rente yaitu pengambilan tambahan dari harta pokok atau modal secara batil, karena samasama mengandung bunga (interest) uang, maka hukumnya sama pula.

Dengan demikian, dapat disimpulkan bahwa fatwa Lajnah Bahtsul Masa'il NU, Majelis Tarjih dan Tajdid Muhammadiyah, dan Dewan Syariah Nasional MUI tentang pengharaman bunga bank, memang merupakan momentum yang sangat menentukan bagi perkembangan perbankan syari'ah di tanah air. Namun mengingat sifat ataupun karakteristik fatwa sebagai produk pemikiran hukum para ulama yang kedudukannya tidak sekuat undang-undang (hukum positif), perkembangan perbankan syari'ah yang diidamkan, hanya mungkin dengan menindak lanjuti fatwa tersebut, dengan tindakan-tindakan kongkrit.

\section{Daftar Pustaka}

Abdul Aziz Muhammad Azzam, 2010. Fiqh Muamalah Sistem Transaksi dalam Fiqh Islam, Jakarta: Amzah

A Partanto, Pius dan M. Dahlan al-Barry, Kamus Ilmiah Populer, Surabaya: Arkola As-Sayyid Sabiq, Fiqh as-Sunnah, Terjemahan cet. Jilid 4 Beirut: Dar al-Fikr, 1403/1983

Az-Zuhaili, Wahbah. 2008. Al-Figh al-Islami wa Adillatubu, Beirut: Dar al-Fikr

Dimyauddin Djuwaini, 2008. Pengantar Fiqh Muamalah, Yogyakarta: Pustaka Pelajar

El- Diwany, Tarek. 2008. Bunga Bank dan Masalahnya, Jakarta Timur: Akbar

Fatwa Majlis Tarjih Muhamadiyah No. 8 Th 2006

Fatwa MUI Nomor 1 Tahun 2004 tentang Bunga

Moh. Nashiruddin A. Ma'mun, S.H.I., M.Hum.Perspektif Nu Tentang Bunga Bank (Refleksi Hasil Mu'tamar Nu Ke-2 Tabun 1927 Di Surabaya Dan Munas 'Alim Ulama Di Bandar Lampung Tahun 1992).Jurnal Ummul Qura Vol. 5 No. 1, Maret 2015.

Moleong, Lexy. 2013. Metode Penelitian Kualitatif (edisi revisi). Bandung: Rosdakarya

Mughits, Abdul. 2009. Ketidakpastian jenis dan Kriteria Hukum Riba dalam Perspektif Pemikiran Ulama. (Jurnal Asy-Syir'ah Vol. 43 No. 1.

Nafik H.R. Muhammad, 2009. Benarkah Bunga Haram? Surabaya, Amanah Pustaka

Nawawi, Ismail. 2012. Fikih Muamalah Klasik dan Kontemporer, Bogor: Ghalia Indonesia 
Nanang Novandra, Keharaman Bunga Bank Menurut Fatwa Majelis Tarïh Mubammadiyah No. 08 Tabun 2006 (Studi Tentang Metode Penetapan Hukumnya). Jurnal Tajdida, Vol. 8 No. 2, Desember 2010.

Syafi'I Antonio, Muhammad. 2001. Bank Syari'ab dari Teori ke Praktek, Jakarta : Gema Insani

Sudarsono, Heri. 2007. Bank dan Lembaga Kenangan Syariab Deskripsi dan Ilustrasi. Yogyakarta: Ekonisia UII,

Zuhri, Muh. 1996. Riba dalam Al-Qur'an dan Masalab Perbankan: Sebuah Tilikan Antisipatif, (Jakarta: PT. RajaGrafindo Persada, 